\title{
Detection and Molecular Characterization of Human Group C Rotavirus in Brazil
}

\author{
Irene Trigueiros Araújo Marcos Bryan Heinemann Alexandre Madi Fialho \\ José Paulo Gagliardi Leite \\ Laboratório de Virologia Comparada e Ambiental, Instituto Oswaldo Cruz, Fiocruz, Manguinhos, Brazil
}

\author{
Key Words \\ Gastroenteritis - Group C rotavirus - Structural proteins • \\ Non-structural proteins $\cdot$ Phylogenetic analysis
}

\begin{abstract}
Objective: The aim of the present study was to characterize 24 isolates of group $C$ rotavirus (RV-C) by analysis of DNA sequences of the VP4, VP6, VP7 and NSP4 genes of several Brazilian states. Methods: All RV-C strains were confirmed by polyacrylamide gel electrophoresis and were characterized by sequence and phylogenetic analysis of the genes encoding NSP4, VP6, VP4, and VP7 proteins. Results: Analysis of the NSP4 gene from Brazilian strains revealed that the isolates are more closely related to each other than to those of other strains previously published. The VP6 gene showed high homology to Indian strains. The sequences of VP4 and VP7 genes showed two lineages circulating in Brazil in the same region and the same time. Conclusion: These results confirm the transmission of RV-C in Brazil. RV-C infection appears to occur occasionally despite the low detection rate of the virus.

Copyright $\odot 2011$ S. Karger AG, Basel
\end{abstract}

I.T.A. and M.B.H. contributed equally to this work.

\section{Introduction}

Rotaviruses belong to the Reoviridae family and are one of the most common causes of acute viral gastroenteritis in humans and animals throughout the world. Family members are classified into seven groups (A-G) based on the antigenic and genetic properties of the major capsid protein VP6. The virus particle has a genome consisting of 11 double-stranded RNA (dsRNA) segments, which encode six structural (VP1 to VP4, VP6 and VP7) and six non-structural (NSP1-NSP6) proteins [1]. The non-structural protein NSP4, encoded by gene 10, is a glycoprotein that anchors in the membrane of the endoplasmic reticulum. NSP4 has been extensively studied in group A rotaviruses due to its role in viral morphogenesis and its enterotoxigenic potential [2-4]. Although human group A rotaviruses represent the most prevalent group worldwide, non-group A rotaviruses are also of epidemiological relevance. Group C rotaviruses (RV-C) have been identified in various age groups, predominantly in sporadic cases and in outbreaks of gastroenteritis. Also, $\mathrm{RV}-\mathrm{C}$ infection has been described in numerous countries, thus demonstrating the epidemiological importance of this agent as an emerging human pathogen [5-8]. The difficulty in diagnosing RV-C infection relates mostly to ELISA, which does not recognize specific group C antigens. Sequence analysis comparison suggests that ge-

José Paulo Gagliardi Leite

Laboratório de Virologia Comparada e Ambiental, Instituto Oswaldo Cruz Fiocruz, Av. Brasil 4365

Manguinhos, RJ 21040-360 (Brazil)

Tel./Fax +552125602921 or 2562 1851, E-Mail jpgleite@ ioc.fiocruz.br
(C) 2011 S. Karger AG, Basel

0300-5526/11/0545-0261\$38.00/0 
Table 1. Information about the samples collected: date, location, sex and age of the patients infected

\begin{tabular}{|c|c|c|c|c|c|c|}
\hline \multirow{2}{*}{$\begin{array}{l}\text { Sample } \\
\text { No. }\end{array}$} & \multirow[t]{2}{*}{ Date } & \multirow[t]{2}{*}{ City } & \multirow[t]{2}{*}{ State } & \multirow[t]{2}{*}{ Sex } & \multicolumn{2}{|l|}{ Age } \\
\hline & & & & & year & month \\
\hline 6325 & $06 / 2003$ & Rio de Janeiro & RJ & $\mathrm{F}$ & 0 & 3 \\
\hline 6532 & $07 / 2003$ & Rio de Janeiro & RJ & M & 0 & 6 \\
\hline 6534 & $07 / 2003$ & NI & RJ & $\mathrm{F}$ & 2 & 0 \\
\hline 6542 & $07 / 2003$ & São Gonçalo & RJ & M & 0 & 6 \\
\hline 7128 & $10 / 2003$ & Parati & $\mathrm{RJ}$ & M & 10 & 0 \\
\hline 7561 & $11 / 2003$ & NI & BA & M & NI & $\mathrm{NI}$ \\
\hline 7946 & $02 / 2004$ & NI & BA & $\mathrm{F}$ & NI & NI \\
\hline 8063 & $03 / 2004$ & NI & BA & M & NI & NI \\
\hline 8346 & $04 / 2004$ & NI & BA & $\mathrm{F}$ & NI & NI \\
\hline 8368 & $04 / 2004$ & NI & BA & $\mathrm{F}$ & NI & $\mathrm{NI}$ \\
\hline 8426 & $05 / 2004$ & Parobé & RS & M & 0 & 4 \\
\hline 8578 & $05 / 2004$ & $\mathrm{NI}$ & BA & M & NI & NI \\
\hline 9288 & $08 / 2004$ & São Pedro da Serra & RS & $\mathrm{F}$ & 0 & 6 \\
\hline 9291 & $08 / 2004$ & Feliz & RS & $\mathrm{M}$ & 33 & 0 \\
\hline 9298 & $08 / 2004$ & Feliz & RS & $\mathrm{F}$ & 57 & 0 \\
\hline 9314 & $08 / 2004$ & NI & RS & $\mathrm{F}$ & 0 & 5 \\
\hline 9315 & $08 / 2004$ & NI & RS & $\mathrm{F}$ & 0 & 6 \\
\hline 9510 & $09 / 2004$ & Farroupilha & RS & $\mathrm{F}$ & 31 & 0 \\
\hline 9515 & $09 / 2004$ & Farroupilha & RS & $\mathrm{F}$ & 29 & 0 \\
\hline 9517 & $09 / 2004$ & Farroupilha & RS & $\mathrm{F}$ & 10 & 0 \\
\hline 9717 & $09 / 2004$ & Caxias do Sul & $\mathrm{RS}$ & M & 0 & 6 \\
\hline 9782 & $10 / 2004$ & Conceição das Alagoas & MG & $\mathrm{F}$ & 4 & 0 \\
\hline 10006 & $10 / 2004$ & Bento Gonçalves & $\mathrm{RS}$ & $\mathrm{F}$ & 24 & 0 \\
\hline 10007 & $10 / 2004$ & Bento Gonçalves & RS & M & 17 & 0 \\
\hline
\end{tabular}

$\mathrm{BA}=$ Bahia MG = Minas Gerais; RJ = Rio de Janeiro; RS = Rio Grande do Sul; NI = not informed.

netic diversity exists among human RV-C isolates, although such diversity is greatest in group A rotaviruses [9]. Molecular epidemiology studies indicate that human $\mathrm{RV}-\mathrm{C}$ evolved relatively recently and constitutes a single genotype distributed around the world $[1,5,10]$. Here, we report the detection of RV-C in Brazil. NSP4, VP6, VP4, and VP7 gene sequences were determined from these samples, and their genetic relationships were compared to the corresponding genes of human RV-C proteins that are globally distributed.

\section{Material and Methods}

Fecal Samples and Polyacrylamide Gel Electrophoresis

Stool specimens from patients with diarrhea were collected between 1997 and 2007 from hospitals located in different regions of Brazil: Rio Grande do Sul State, 12 samples (South Region); Rio de Janeiro State, 5 samples; Minas Gerais State, 1 sample (Southeast Region); Bahia State, 6 samples (Northeast Region). Samples were stored at $-20^{\circ}$ prior to analysis (table 1 ). Samples were routinely screened by ELISA to detect group A rotavirus antigens ac- cording to Pereira et al. [11]. All samples were negative for common bacterial pathogens, infection by several parasites, group A rotavirus, and adenovirus. The presence of RV-C in fecal extracts was confirmed, prior to genotyping, by analysis of dsRNA using polyacrylamide gel electrophoresis (PAGE). dsRNA segments were detected and electrophoretically characterized using PAGE followed by silver staining according to Pereira et al. [12].

\section{RT-PCR Amplification}

Nucleic acids were extracted from fecal suspensions using the silica powder glass extraction method as described by Boom et al. [13]. Purified viral dsRNA was reverse transcribed (RT) using SuperScript ${ }^{\circledR}$ Reverse Transcriptase (Invitrogen, Carlsbad, Calif., USA), and PCR amplification was performed with Platinum Taq DNA polymerase ${ }^{\circledR}$ (Invitrogen). The NSP4 gene protein was amplified using primers and a PCR protocol described by Chang et al. [14]. For the VP6 gene, a set of primers was designed from the available sequence of Cowden gene 6 (GenBank accession M94157): VP6 sense 5'-AATACATGTCAACTTGCA-3', nucleotides 577-594, and VP6 antisense 5'-ATAGTTCACATTTCATCC$3^{\prime}$, nucleotides 1329-1346. The reaction conditions included a denaturing step at $94^{\circ}$ for $3 \mathrm{~min}$, followed by 35 cycles with consecutive steps of denaturing $\left(94^{\circ}, 30 \mathrm{~s}\right)$, annealing $\left(50^{\circ}, 30 \mathrm{~s}\right)$, and elongation $\left(72^{\circ}, 30 \mathrm{~s}\right)$ and a final elongation step at $72^{\circ}$ for $5 \mathrm{~min}$. 
For the VP4 and VP7 genes, we used primers T434 and T435 for VP4 (843 bp), for VP7 primers T348 and T727 (341 bp) and an RT-PCR method described previously by Adah et al. [6]. Positive and negative controls were used in all procedures, and recommended operations for PCR techniques were carried out as a precaution to avoid false results.

\section{DNA Sequencing and Phylogenetic Analysis}

PCR amplified products of the NSP4, VP6, VP4, and VP7 were purified using a commercial kit (QIAquick ${ }^{\circledR}$ PCR purification kit, Qiagen Inc., Valencia, Calif., USA) and sequenced with both forward and reverse primers using the BigDye ${ }^{\circledR}$ Terminator Kit (Applied Biosystems, Foster City, Calif., USA) with an automated sequencer (ABI Prism 3100 automatic sequencer; Applied Biosystems) according to the manufacturer's instructions. The complete sequence assemblies were created with the PHRED/PHRAP [15] and CAP3 [16] programs using nucleotide data with quality values $>20$. The derived RV-C sequences were aligned using BioEdit v. 7.0.5 [17].

Phylogenetic analysis was performed at nucleotide level on the aligned dataset and was carried out using the neighbor-joining algorithm and maximum composite likelihood evolutionary model implemented in Mega $4.1^{\mathcal{O}}$ [18] with 1,000 bootstrap replicates. Porcine and bovine $\mathrm{RV}-\mathrm{C}$ sequences were used as an outgroup. The bootstrap value cutoff was $65 \%$.

Nucleotide sequence data reported are available in the GenBank databases under the following accession numbers: EF029891 to EF029894; EF029896; EF029899 to EF029900; EF029902 to EF029906; EF029908 to EF029912; EF029916 to 029922 for NSP4 gene; FJ211024 to FJ211026; FJ211028; FJ211029; FJ211032; FJ211033; FJ211035; FJ211036; FJ211038; FJ211040 to FJ211043 for VP6 gene; FJ619575 to FJ619598 for VP4 gene and FJ619599 to FJ619622 for VP7 gene.

\section{Results}

\section{PAGE and PCR Amplification}

PAGE analysis of viral dsRNA from stool samples demonstrated that all 24 specimens exhibited characteristic 4-3-2-2 migration patterns typical of RV-C. PCR amplification generated expected molecular masses of 583, 770, 843, and 341 bp for NSP4, VP6, VP4 and VP7 genes, respectively.

\section{Age Distribution}

The mean and median ages were 12 and 3 years, respectively. The minimum age was 6 months and the maximum was 57 years (table 1).

\section{Sequence Analysis}

In order to define the genetic relationship between human RV-C circulating in Brazil and other countries, the sequences of the NSP4, VP6, VP4, and VP7 genes from Brazilian strains were determined. The sequences of Bra-

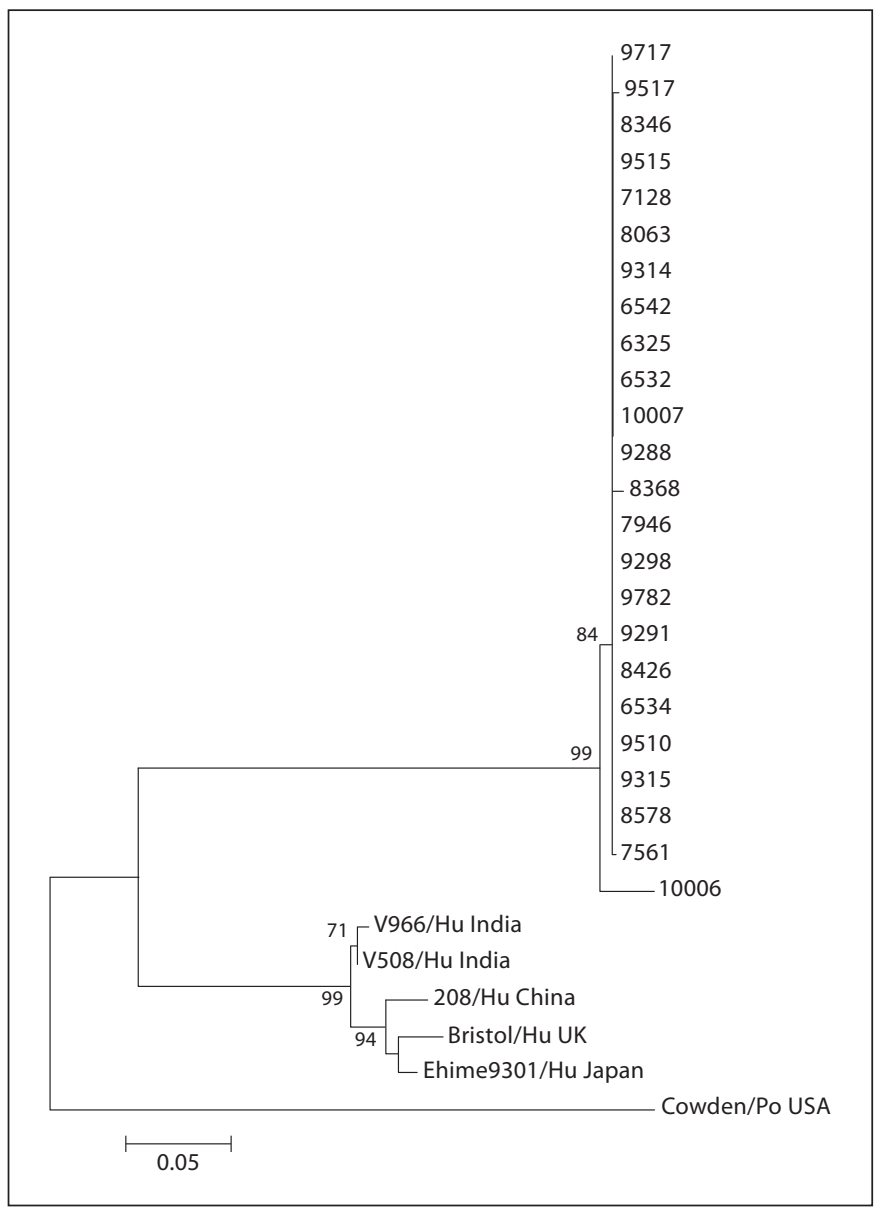

Fig. 1. Phylogram demonstrating the genealogical relationship between NSP4 genes from human and porcine RV-C. NSP4 sequence data of the published strains were obtained from the GenBank databases under the following accession numbers: 208; AB008673; Bristol, X83497; Cowden, AF093202; Ehime 9301, D88353; V508, AY770976; V966, AY941786.

zilian strains were genetically related to each other, since identities ranged from 96.2 to $100 \%$ at the nucleotide level and from 94.6 to $100 \%$ at the amino acid level for NSP4 gene. We also observed sequence identities of $97.9-100 \%$ at the nucleotide level and $93.3-100 \%$ at the amino acid level for VP6, 91.7-100\% at the nucleotide level and 87.2$100 \%$ at the amino acid level for VP4, and $94.2-100 \%$ at the nucleotide level and $92.9-100 \%$ at the amino acid level for VP7. Phylogenetic trees for the NSP4, VP6, VP4, and VP7 genes were constructed in order to perform a comparative analysis of each nucleotide sequence.

The NSP4 phylogenetic tree showed that Brazilian strains were more closely related to one another than to strains found elsewhere in the world and two main clus- 


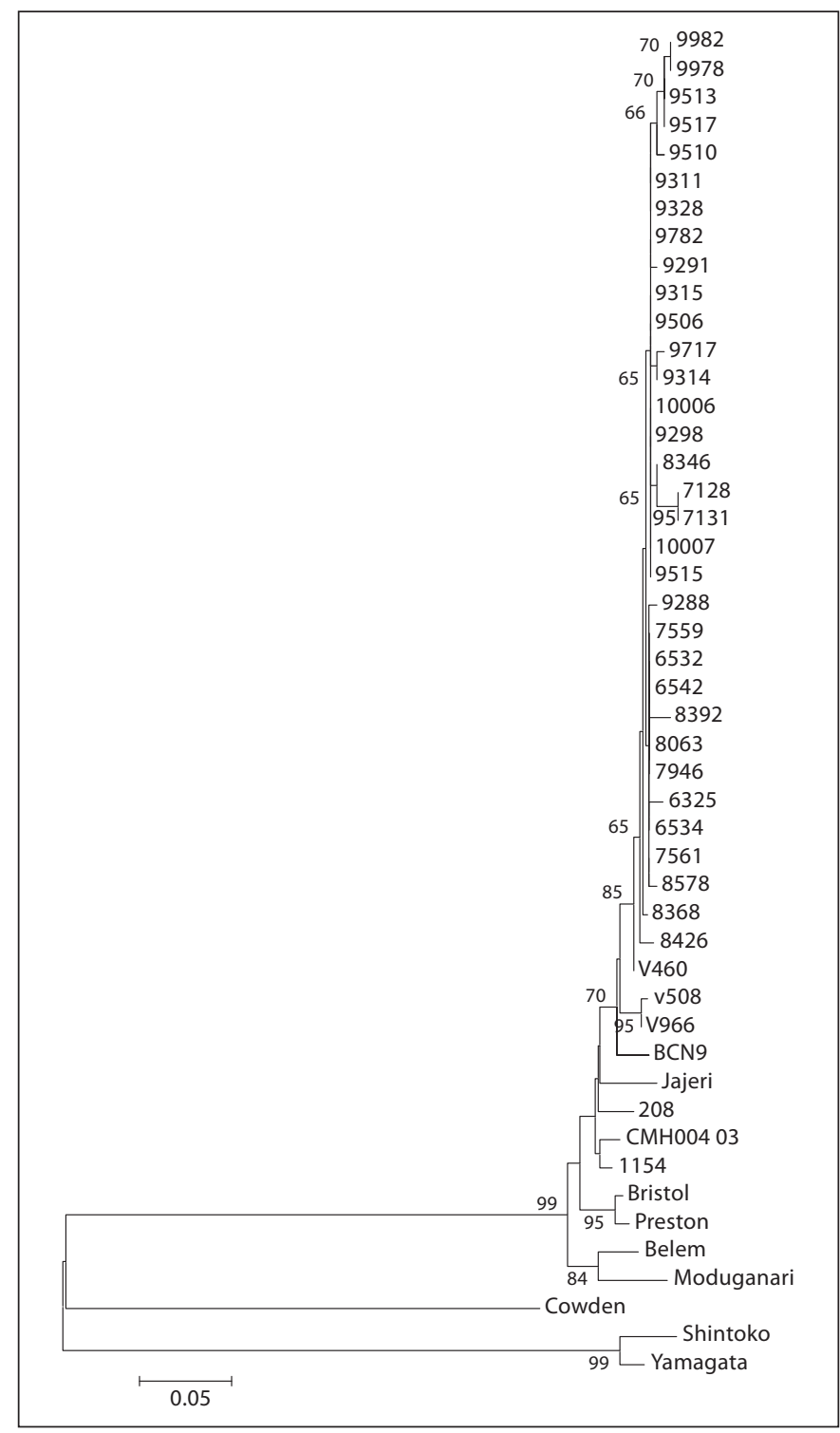

Fig. 2. Phylogram demonstrating the genealogical relationship between VP6 genes from human, bovine, and porcine RV-C. VP6 sequence data of the published strains were obtained from the GenBank databases under the following accession numbers: 208, AB008672; BCN9, AM118019; Belem, M94155; Bristol, X59843; CNH004/03, EF641110; Cowden, M94157; Jajeri, AF325805; Moduganari, AF325806; Preston, M94156; PA23997-34, EF635974; PA24002-75, EF635976; PA24183-48, EF635993; Shintoku, M88768; Yamagata, AB108680; V460, AY786570; V508, AY770980; V966, AY786571.

ters were observed. All Brazilian sequences grouped into a single cluster, suggesting a separate genogroup (fig. 1). Analysis of the VP6 gene showed the Brazilian strains more closely related to sequences from Spain and India, but distinct from sequence described in Para (Belem

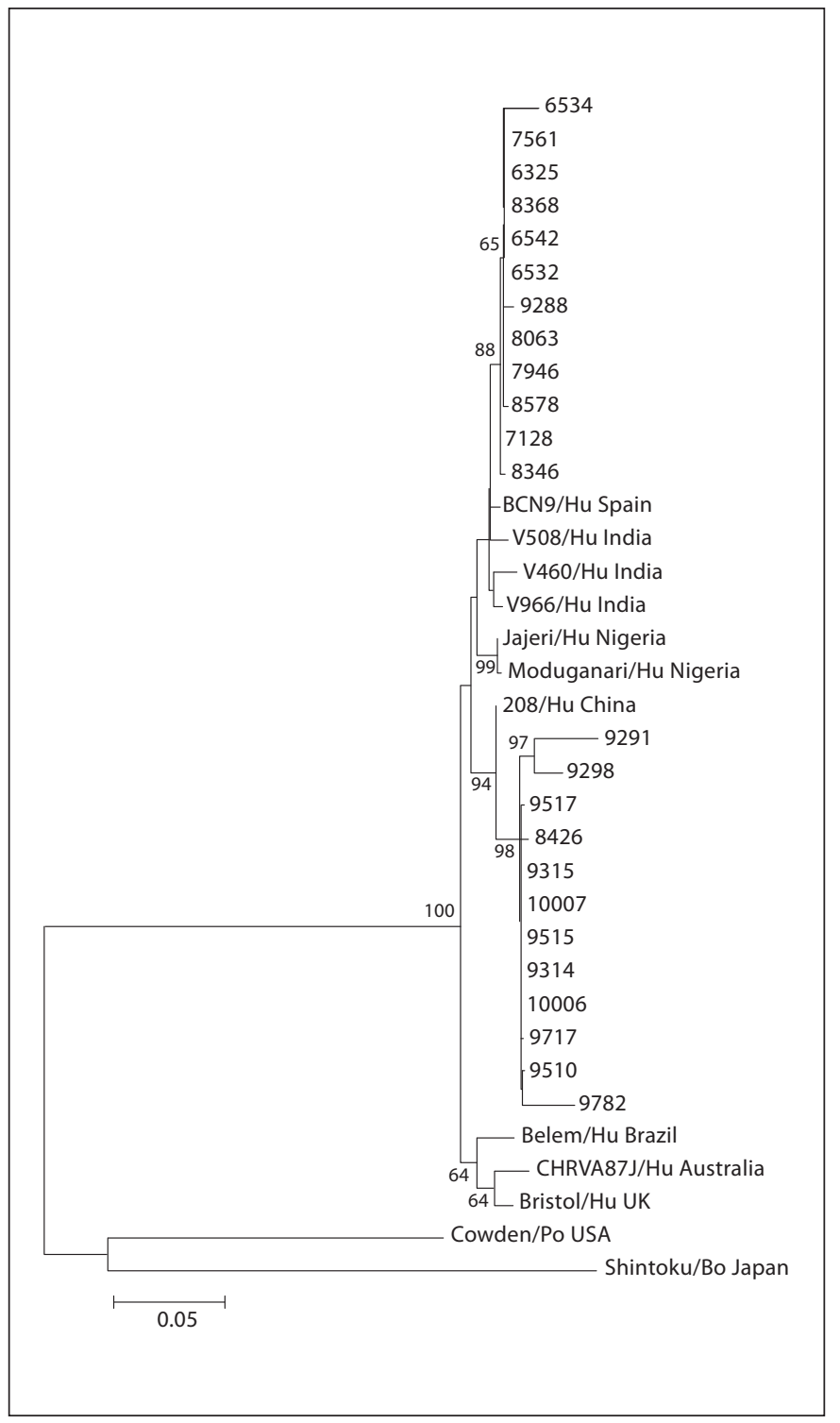

Fig. 3. Phylogram demonstrating the genealogical relationship between VP4 genes from human, bovine, and porcine RV-C. VP4 sequence data of the published strains were obtained from the GenBank databases under the following accession numbers: 208, AB008670; BCN9, AM118025; Belem, X79441; Bristol, X79442; CHRVA87J, AY395069; Cowden, M74218; Jajeri, AF323981; Moduganari, AF323980; Shintoku, U26551; V460, AY795897; V508, AY795895; V966, AY795896.

strain), North Brazil - these isolates formed a separate subgroup with sequences from Nigeria (fig. 2).

VP4 gene analysis showed that Brazilian strains fall into two separate subgroups. One subgroup, showing a bootstrap value of $98 \%$, is closely related to the Chinese 


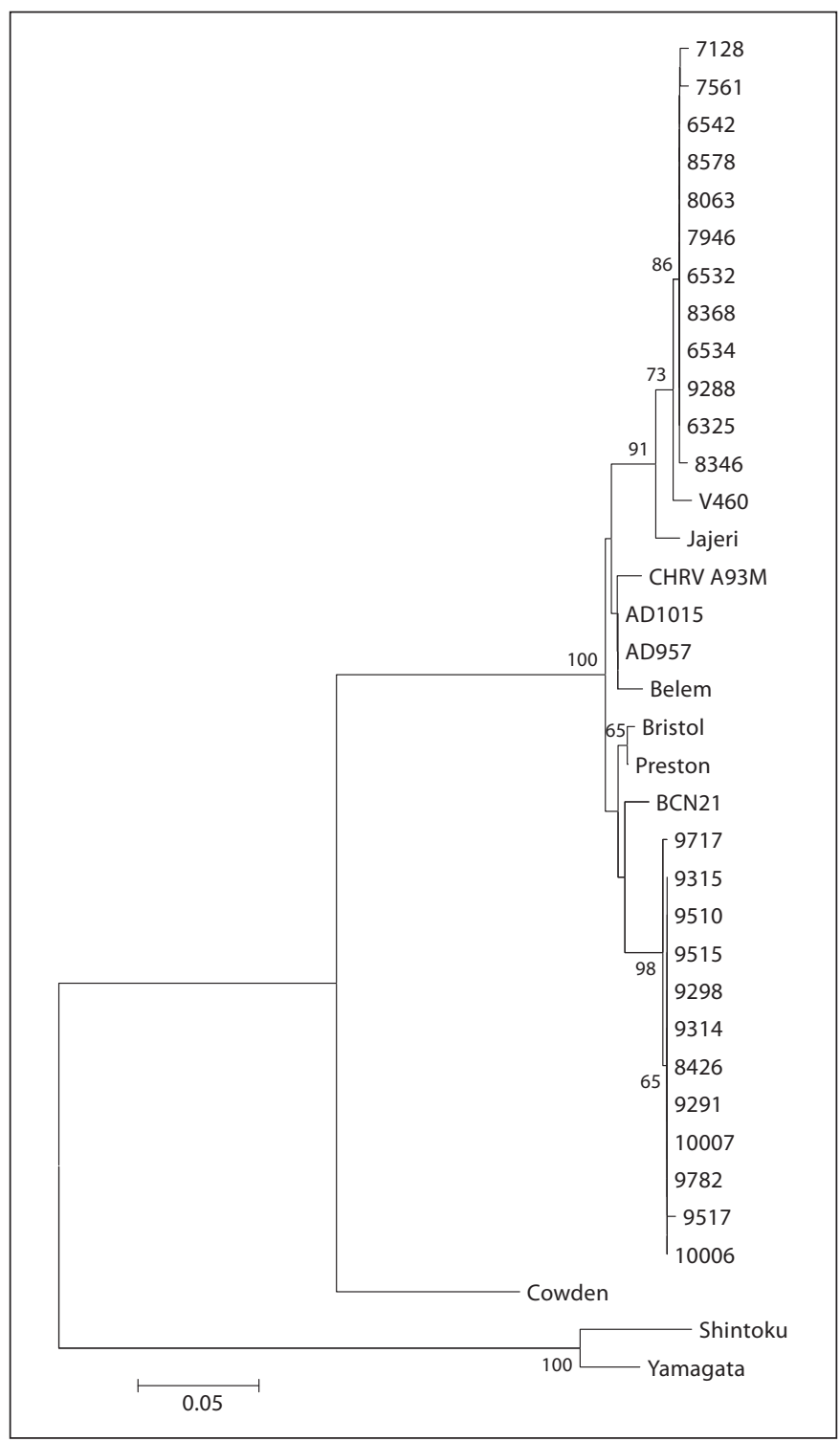

Fig. 4. Phylogram demonstrating the genealogical relationship between VP7 genes from human, bovine, and porcine RV-C. Accession numbers: AD1015, U20994; AD957, U20993; BCN21, AM118023; Belem, X77256; Bristol, X77257; CHRV/A93M, AY392447; CMH004/03, EF641111; Cowden, M61101; Jajeri, AF323982; Moduganari, AF323979; Preston, X77258; Shintoku, U31750; Yamagata, AB108681; V460, AY803724.

208 strain isolated in the mid-1990s. The other subgroup clusters with sequences from India, Spain, and Nigeria (fig. 3). The VP7 genes also formed two separate clusters in the phylogenetic tree (bootstrap value of $100 \%$ ). One cluster formed by the Brazilian strains was closely related to the Spanish BCN21 strain and the UK Preston and Bristol strains. The other Brazilian strains clustered with those published from different regions of the world (India, Nigeria, Thailand, Australia and USA), including one strain from Belem, Brazil (fig. 4). All human RV-C strains analyzed for the NSP4, VP6, VP4, and VP7 genes in this study were distantly related to RV-C of porcine and bovine origins.

\section{Discussion}

There are few studies of RV-C in Brazil [10, 19-23]. This is the first RV-C study that characterizes NSP4, VP6, VP4, and VP7 genes from Brazilian strains. According to a number of seroepidemiological surveys, RV-C occurs at lower frequencies than group A rotaviruses; however, the distribution of $\mathrm{RV}-\mathrm{C}$ shows that infection by these viruses occurs more commonly than previously believed $[1,5$, 24-27].

In the present study, RV-C was detected in different age groups. Nilsson et al. [28], in a prospective study in Sweden, found that $1 \%$ of diarrhea in adults is caused by $\mathrm{RV}-\mathrm{C}$, while no cases occur among children. This study is different from the reports by Castello et al. [5], Schnagl et al. [7], and Abid et al. [29], who all detected the agent in children $<3$ years of age, a pattern similar to that of group A rotavirus infection. The same pattern was observed by Castello et al. [27] in Argentina, where no differences were detected between the ages of patients with rotavirus group A and C. Schnagl et al. [7] and Castello et al. [27] detected RV-C continuously over a 5-year period, in Australia and Argentina, respectively. Castello et al. [27] also observed that RV-C showed no seasonality, being distributed throughout the year.

In contrast to these results, we did not observe this pattern (table 1). These variable detection rates could be caused by multiple factors, including the intrinsic characteristics of group $\mathrm{C}$ rotavirus, sampling and detection methods [27].

Our NSP4 gene analysis indicated two distinct sets of strains (fig. 1). The Brazilian set was split in two 'sister groups', supported by a bootstrap value of $99 \%$. One cluster is formed by the majority of the isolates from separate Brazilian states in different years, showing that there is not any time or space difference among the samples in this group. The other cluster is formed by the strain 10006, isolated in Bento Gonçalves (Rio Grande do Sul State), in 2004. Also from Bento Gonçalves, in 2004, the sample 10007 was isolated and shared $94.6 \%$ identity with 
sample 10006, suggesting the circulation of at least two genetic profiles of the NSP4 gene in this municipality. Analysis of the Brazilian VP6 gene sequences (fig. 2) revealed that these strains are host restricted and of human origin, distinct from the 14 strains analyzed in Belem and from those reported of porcine origin [23].

The VP4 and VP7 gene sequences formed two separate clusters in the evolutionary tree, making evident the simultaneous circulation of two lineages of RV-C in Brazil. Analysis of both genes showed that eleven isolates from the South Central Region of Rio Grande do Sul clustered together. These data indicate that these viruses entered circulation in May 2004 and lasted through October 2004. Another lineage was circulating before June 2003 in Rio de Janeiro and emerged in Bahia in November 2003. Isolate 9288 from Rio Grande do Sul appeared in August 2004, which demonstrates the circulation of two lineages at the same time and region in Rio Grande do Sul (fig. 3, 4). Our laboratory is responsible for the epidemiological surveillance of viral gastroenteritis in several Brazilian states, and RV-C was not detected in the years 2005-2007.
Our results indicate the need for broader epidemiological surveillance of cases of diarrhea caused by RV-C in adults and children. Additionally, our results show a need for the monitoring of genetic diversity of this etiologic agent in Brazil and in the rest of the world in order to establish a link between the genotypes and the intensity of the clinic symptoms. These findings indicate that $\mathrm{RV}-\mathrm{C}$ has an important role in acute gastroenteritis in hospitalized children and adults. Furthermore, this study contributes to a better understanding of the molecular epidemiology of rotaviruses in Brazil.

\section{Acknowledgments}

This research study was supported by the National Council for Scientific and Technological Development (CNPq), IOC-FIOCRUZ and CGLAB/SVS/Ministry of Health, Brazil. M.B.H. received a research fellowship from $\mathrm{CNPq} /$ Fiocruz. I.T.A. received a research fellowship from FAPERJ/Fiocruz.

\section{References}

1 Jiang B, Tsunemitsu H, Dennehy PH, Oishi I, Brown D, Schnagl RD, Oseto M, Fang ZY, Avendano LF, Saif LJ, Glass RI: Sequence conservation and expression of the gene encoding the outer capsid glycoprotein among human group $\mathrm{C}$ rotaviruses of global distribution. Arch Virol 1996;141:381-390.

-2 Ball JM, Tian P, Zeng CQY, Morris AP, Estes MK: Age-dependent diarrhoea induced by a rotaviral nonstructural glycoprotein. Science 1996;272:101-104.

3 Estes MK: Rotaviruses and their replication; in Knipe DM, Howley PM, Griffin DE, Lamb RA, Martin MA, Roizman B, Strais E (eds): Fields Virology, ed 4. Philadelphia, Lippincott Williams \& Wilkins, 2001, pp 17471785.

-4 Sánchez-Fauquier A, Roman E, Colomina J, Wilhelmi I, Glass RI, Jiang B: First detection of group $\mathrm{C}$ rotavirus in children with acute diarrhea in Spain. Arch Virol 2003;148:399_ 404.

5 Castello AAMH, Arguelles GA, Villegas NL, Ghiringhelli DP, Semorile L, Glikmannn G: Characterization of human group $C$ rotavirus in Argentina. J Med Virol 2000;62:199207.

6 Adah MI, Wade A, Oseto M, Kuzuya M, Taniguchi K: Detection of human group C rotavirus in Nigeria and sequence analysis of their genes encoding VP4, VP6, and VP7 proteins. J Med Virol 2002;66:269-275.
7 Schnagl RD, Boniface K, Cardwell P, McCarthy D, Ondracek C, Coulson B, Erlich J, Morey F: Incidence of group $C$ human rotavirus in Central Australia and sequence variation of the VP7 and VP4 genes. J Clin Microbiol 2004;42:2127-2133.

-8 Esona MD, Humphrey CH, Dennehy PH, Jiang B: Prevalence of group C rotavirus among children in Rhode Island, United States. J Clin Virol 2008;2:221-224.

$\checkmark 9$ Rahman M, Banik S, Faruque ASG, Taniguchi K, Sack DA, van Ranst M, Azim T: Detection and characterization of human group $\mathrm{C}$ rotavirus in Bangladesh. J Clin Microbiol 2005;43:4460-4465.

10 Gabbay YB, Jiang B, Oliveira CS, Mascarenhas JDP, Leite JP, Glass RI, Linhares AC: An outbreak of group $\mathrm{C}$ rotavirus gastroenteritis among children attending a day-care center in Belém, Brazil. J Diarrhoeal Dis Res 1999; 17:69-74.

-11 Pereira HG, Azeredo RS, Leite JPG, Andrade $\mathrm{ZP}$, Castro L: A combined enzyme immunoassay for rotavirus and adenovirus (EIARA). J Virol Methods 1985;10:21-28.

12 Pereira HG, Azeredo RS, Leite JPG, Candeias JAN, Racz ML, Linhares AC, Gabbay YB, Trabulsi JR: Electrophoretic study of the genome of human rotaviruses from Rio de Janeiro, São Paulo and Belém, Brazil. J Hyg 1983;90:117-125.
13 Boom R, Sol CJA, Salimans MMM, Jansen CL, Wertheim-Van Dillen PME, Van Der Noordaa J: Rapid and simple method for purifications of nucleic acids. J Clin Microbiol 1990;28:495-503.

14 Chang KO, Kim YJ, Saif LJ: Comparisons of nucleotide and deduced amino acid sequences of NSP4 genes of virulent and attenuated pairs of group A and C rotaviruses. Virus Genes 1999; 18:229-233.

15 Ewing B, Green P: Base-calling of automated sequencer traces using phred. II. Error probabilities. Genome Res 1998;8:186-194.

16 Huang X, Madan A: CAP3: A DNA sequence assembly program. Genome Res 1999;9: 868-877.

17 Hall TA: BioEdit: a user-friendly biological sequence alignment editor and analysis program for Windows 95/98/NT. Nucl Acids Symp Ser 1999;41:95-98.

18 Tamura K, Dudley J, Nei M, Kumar S: MEGA4: Molecular Evolutionary Genetics Analysis (MEGA) software version 4.0. Mol Biol Evol 2007;24:1596-1599.

19 Timenetsky MCST, Kisielus JJ, Grisi SJFE, Escobar AMU, Ueda M, Tanaka H: Rotavirus, adenovirus, astrovirus, calicivirus e 'small round virus particles' em fezes de crianças com e sem diarréia aguda no período de 1987 a 1988 na grande São Paulo. Rev Inst Méd Trop São Paulo 1993;35:275-280. 
20 Cox MJ, James VLA, Azevedo RS, Massad E, Medley GF: Infection with group C rotavirus in a suburban community in Brazil. Trop Med Int Health 1998;3:891-895.

-21 Souza DFC, Kisielius JJ, Ueda M, Gabbay YB, Carmona RCC, Timenetsky MCST: An outbreak of group $\mathrm{C}$ gastroenteritis among adults living in Valentin Gentil, São Paulo State, Brazil. J Diarrhoeal Dis Res 1998;16: 59-65.

-22 Teixeira JMS, Câmara GNNL, Pimentel PFV, Ferreira MNR, Alfieri AA, Gentsch JR, Leite JPG: Human group $C$ rotavirus in children with diarrhea in the Federal District, Brazil. Braz J Med Biol Res 1998;31:1397-1403.
23 Gabbay YB, Borges AA, Oliveira DS, Linhares AC, Mascarenhas JPD, Barardi CRM, Simões CMO, Wang Y, Glass RI, Jiang B: Evidence for zoonotic transmission of group $C$ rotaviruses among children in Belém, Brazil. J Med Virol 2008;80:1666-1674.

24 Steele AD, James VL: Seroepidemiology of human group C rotavirus in South Africa. J Clin Microbiol 1999;37:4142-4144.

25 Sasaki S, Horie Y, Nakagomi T, Oseto M, Nakagomi O: Group C rotavirus NSP4 induces diarrhea in neonatal mice. Arch Virol 2001; 146:801-806.

26 Steyer A, Poljsak-Prijatelj M, Bufon T, Sedmak M, Vidmar L, Mijovski JZ, Marin J: First detection of group $\mathrm{C}$ rotavirus in patients with gastroenteritis in Slovenia. J Med Virol 2006;78:1250-1255.
27 Castello AA, Argüelles MH, Rota RP, Humphrey CD, Olthoff A, Gentsch JR, Glass RI, Glikmann G, Jiang B: Detection and characterization of group $\mathrm{C}$ rotavirus in Buenos $\mathrm{Ai}$ res, Argentina, 1997-2003. J Med Virol 2009; 81:1109-1116.

28 Nilsson M, Svenungsson B, Hedlund K, Uhnoo I, Lagergren A, Akre T, Svensson L: Incidence and genetic diversity of group $\mathrm{C}$ rotavirus among adults. J Infect Dis 2000; 182:678-684.

29 Abid I, Guix S, Aouni M, Pinto R, Bosch A: Detection and characterization of human group $\mathrm{C}$ rotavirus in the pediatric population of Barcelona, Spain. J Clin Virol 2007; $38: 78-82$. 